\title{
Haematological Parameters of the Hybrid Surubim (Pseudoplatystoma reticulatum $x P$. corruscans) farmed in Brazil
}

\author{
Gabriela Tomas Jerônimo ${ }^{1 *}$, Aline Brum ${ }^{1}$, Santiago Benites de Pádua ${ }^{2}$, Eduardo Luiz \\ Tavares Gonçalves ${ }^{1}$, Robson Soares Capecci ${ }^{1}$, Márcia Mayumi Ishikawa ${ }^{3}$ and Maurício \\ Laterça Martins ${ }^{1}$ \\ ${ }^{1}$ Laboratório AQUOS - Sanidade de Organismos Aquáticos; Departamento de Aquicultura; Universidade Federal \\ de Santa Catarina; Florianópolis - SC - Brasil. ${ }^{2}$ AquiVet Saúde Aquática; São José do Rio Preto - SP - Brasil. \\ ${ }^{3}$ Embrapa Meio Ambiente; Jaguariúna - SP - Brasil.
}

\begin{abstract}
This study evaluated the haematological parameters of the hybrid surubim (Pseudoplatystoma corruscans $x$ P. reticulatum) farmed in intensive and semi intensive system. A total of 240 fish were examined, 120 from fish farm and 120 from a semi-intensive for comparison between the hot and cold season. The water quality was weekly measured to evaluate the influence of environmental conditions on the haematology. Fish from intensive system showed hematocrit and white blood cell count (WBC) higher in hot season while the total plasmatic protein, hemoglobin concentration, mean corpuscular hemoglobin concentration (MCHC) and mean corpuscular volume $(M C V)$ were higher in cold season. In fish from semi intensive system, the red blood cells count (RBC) and total thrombocyte number was higher in hot season while the MCHC and MCV were higher in cold season. There was no alterations in the numbers of lymphocytes, neutrophils, basophils, eosinophils and PAS - positive granular leukocyte (PAS-LG). The results showed the influence of seasonality on the hematological parameters of the hybrid surubim kept under normal farming conditions. Regarding water quality, hot season was directly related to increased water temperature and decreased dissolved oxygen while the opposite was found in cold season.
\end{abstract}

Key words: culture system, hematology, seasonality, Siluriformes

\section{INTRODUCTION}

Brazil currently ranks among the top countries with great growth potential in continental aquaculture. The intense capture of species of economic importance has resulted in decrease of inventory and consequent reduction of natural fish production, leading to increased interest in its cultivation (Crepaldi et al. 2006). Fish of the genus Pseudoplatystoma (Siluriformes) are of great importance, both in fishing and in aquaculture, with significant contribution in the fishing economy of central Brazil (Campos 2005). In 2011, about 1.747 tons of Pseudoplatystoma spp. were grown in fish farms in Brazil, generating revenues of US\$ 3.825.140 (FAO 2013).

Pseudoplatystoma corruscans Spix and Agassiz, 1829 (popularly known in Brazil as "pintado" or "surubim") and $P$. reticulatum Eigenmann and Eigenmann, 1889 (known as "cachara" or "surubim") are migratory carnivorous species, which in adulthood can reach up to $100 \mathrm{~kg}$ and 20 $\mathrm{kg}$, respectively (Campos 2005). In farms, surubins reaches about $2 \mathrm{~kg}$ in just one year

*Author for correspondence: gabrielatj@ gmail.com 
(Zaniboni Filho 2004). The strategy of crossing $P$. corruscans with $P$. reticulatum to produce hybrid fingerlings increased the survival in the hatchery over the cultivation of $P$. corruscans (Naldoni et al. 2009), favoring management practices (Ishikawa et al. 2012). The hybrid surubim shows excellent husbandry for cultivation, high market value, international market potential, good carcass yield, flavor and enjoyed the absence of spines (Labarrère 2012). However, to promote good management practices and optimize production, it is necessary to know their biological peculiarities (Ishikawa et al. 2012).

The intensive fish farming is responsible for constant pressure in the fish due to the stress caused by high stocking densities, transport, fluctuations in water quality parameters, inadequate nutrition and pressure by pathogens. Thus, the hematological parameters could be interesting tools to show the health condition of the fish (Labarrère et al. 2012). Studies on the hematology of surubim hybrids are still scarce. The morphological description and cytochemistry of leukocytes were reported by Beelen et al. (2003). Later, other studies reported high erythrocyte and total plasma proteins values of surubins hybrids cultured in the state of Mato Grosso do Sul (Tavares-Dias et al. 2009) and under different stocking densities (Labarrère et al. 2012). Some others studies reported hematological changes caused by the infection with Pseudomonas sp. (Tavares-Dias et al. 2009), dietary supplementation symbiotic (Mouriño et al. 2012), experimental infection with Aeromonas hydrophila (Silva et al. 2012), and testing of various blood anticoagulants (Ishikawa et al. 2010). However, little is known about the blood profile of these animals on fish farms, especially in relation to leukocyte number, which is one of the main ways of defense of the immune system (Tavares-Dias et al. 2009). Considering the growing interest, in hybrid surubim farming, in Brazil and the lack of information that could serve as a reference to assess their health status, the objective of this study was to compare the hematological parameters of fish raised in feedlot and fishing ponds, in two seasons (hot and cold).

\section{MATERIAL AND METHODS}

A total of 240 surubins hybrids were captured by dragnet from an intensive system $(n=120)$ and from a semi intensive pond $(n=120)$ from June 2010 to May 2011 in the warm seasons (October to March) and cold (April to September) in State of Mato Grosso do Sul, Brazil. During both the seasons the physico-chemical characteristics of water from fish farms was monitored weekly from 08:00 to 09:00 am. The following parameters were measured: dissolved oxygen, temperature, $\mathrm{pH}$ and electrical conductivity with multiparameter HANNA $^{\circledR}$, transparency (with the aid of Secchi disk) and alkalinity (by titulation method). Samples of output pond water were collected for the determination of orthophosphate, total ammonia, nitrite and nitrate by colorimetric kit (Alfakit ${ }^{\circledR}$, São Paulo, Brazil). The results are shown in Table 1.

Table 1 - Water quality of ponds measured during of seasons of intensive and semi-intensive fish farms.

\begin{tabular}{|c|c|c|c|c|}
\hline \multirow[b]{2}{*}{ Parameters } & \multicolumn{2}{|c|}{ Intensive Farm } & \multicolumn{2}{|c|}{ Semi Intensive Farm } \\
\hline & Cold Season & Hot Season & Cold Season & Hot Season \\
\hline Alcalinity (mg.L $\left.{ }^{-1}\right)$ & $61.55 \pm 5.09$ & $63.29 \pm 10.41$ & $38.56 \pm 4.12$ & $39.67 \pm 8.87$ \\
\hline $\mathrm{pH}$ & $7.25 \pm 0.30$ & $7.36 \pm 0.50$ & $7.13 \pm 0.42$ & $7.35 \pm 0.54$ \\
\hline Eletrical conductivity $\left(\mu \mathrm{S} . \mathrm{cm}^{-1}\right)$ & $72.36 \pm 5.64$ & $77.33 \pm 3.58$ & $25.91 \pm 1.74$ & $26.70 \pm 3.80$ \\
\hline Dissolved Oxygen (mg.L $\left.{ }^{-1}\right)$ & $6.41 \pm 1.04$ & $3.12 \pm 1.32$ & $6.78 \pm 0.81$ & $4.35 \pm 1.29$ \\
\hline Temperature $\left({ }^{\circ} \mathrm{C}\right)$ & $18.90 \pm 2.33$ & $28.75 \pm 0.80$ & $18.97 \pm 3.17$ & $28.29 \pm 0.89$ \\
\hline Transparency $(\mathrm{cm})$ & $40.29 \pm 18.31$ & $25.08 \pm 6.93$ & $25.98 \pm 4.10$ & $19.79 \pm 3.56$ \\
\hline Ammonia (mg. $\left.\mathrm{L}^{-1} \mathrm{NH}_{3}\right)$ & $0.20 \pm 0.10$ & $0.32 \pm 0.20$ & $0.27 \pm 0.07$ & $0.13 \pm 0.05$ \\
\hline Total Iron (mg.L $\left.\mathrm{L}^{-1} \mathrm{Fe}\right)$ & $0.04 \pm 0.09$ & $0.13 \pm 0.17$ & $0.17 \pm 0.17$ & $0.14 \pm 0.27$ \\
\hline Nitrate $\left(\mathrm{mg} \cdot \mathrm{L}^{-1} \mathrm{NO}_{3}\right)$ & $0.19 \pm 0.19$ & $0.15 \pm 0.07$ & $0.19 \pm 0.13$ & $0.29 \pm 0.16$ \\
\hline Nitrite $\left(\mathrm{mg} \cdot \mathrm{L}^{-1} \mathrm{NO}_{2}\right)$ & $0.03 \pm 0.02$ & $0.02 \pm 0.04$ & $0.08 \pm 0.13$ & $0.03 \pm 0.08$ \\
\hline Orthophosphate (mg.L $\left.\mathrm{L}^{-1} \mathrm{PO}_{4}\right)$ & $0.00 \pm 0.00$ & $0.49 \pm 0.41$ & $0.23 \pm 0.36$ & $0.09 \pm 0.26$ \\
\hline
\end{tabular}

After capture, the animals were anesthetized with clove oil $\left(75 \mathrm{mg} \mathrm{L}^{-1}\right)$ for blood collection and its analysis (Ishikawa et al. 2011) (Ethics Committee 29979/2009-05/CEUA/UFSC 23080.0). Blood was 
collected by puncture of the caudal vessel with syringes containing EDTA 3\%, packed, cooled and transported to the laboratory to measure the percentage of hematocrit by the microhematocrit method (Goldenfarb et al. 1971); concentration hemoglobin by the cianometahemoglobin (Collier 1944), erythrocyte count (RBC) in a Neubauer chamber after dilution 1:200 in formalin-citrate, mean corpuscular volume (MCV), mean corpuscular hemoglobin concentration (MCHC) (Wintrobe 1934) and total plasma proteins with portable refractometer. The total numbers of leukocytes (WBC) and thrombocytes were obtained by indirect method from extensions stained with May-Grünwald-Giemsa-Wright (MGGW) (Ishikawa et al. 2008).

Biometric and hematological parameters data were checked for normality, using KolmogorovSmirnov test, and homoscedasticity, using Levene's test and were subjected to the analysis of variance (ANOVA), comparing between the seasons and properties upon satisfying the requirements. Data transformations were used according to pertinence and Tukey's test was used to compare the means at a significance level of $5 \%$. The water quality data were subjected to principal components analysis (PCA) in order to verify the relationship of the variables with the different seasons.

\section{RESULTS AND DISCUSSION}

In principal component analysis conducted with the data from the fishing ponds of semi-intensive system (Fig. 1), the joint representation of the two main factors accounted for $62 \%$ of the variance. A higher correlation between the cold season and high levels of transparency, orthophosphate and dissolved oxygen was obseerved, whereas the hot season was more strongly correlated with higher levels of nitrites, nitrates and temperature. These relationships could be due to lower primary productivity in the ponds during the cold season, associated with higher values of ammonia due to lower capacity of nutrient cycling, followed by increased nitrification as productivity increased in the hot season.
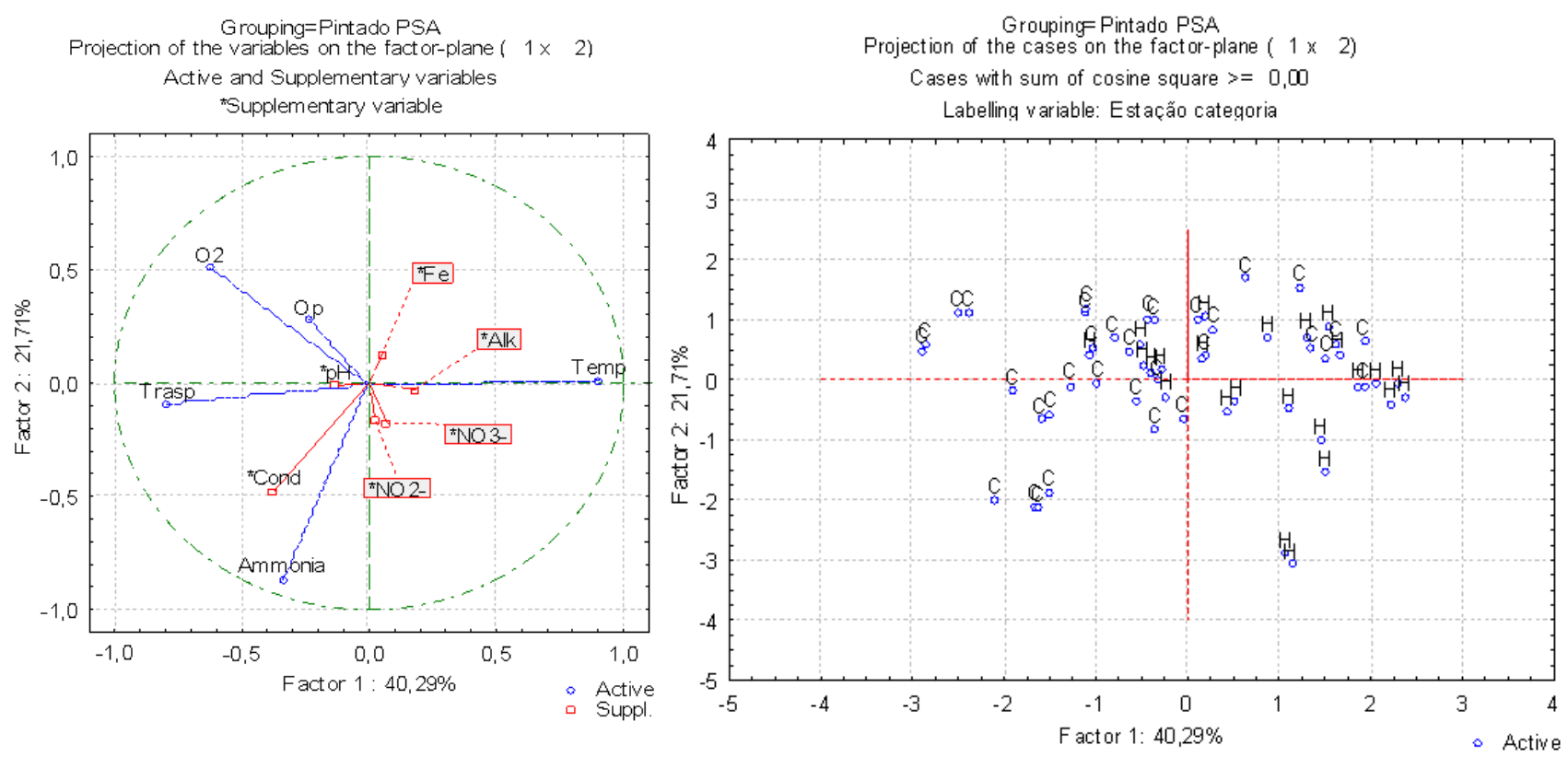

Figure 1 - Principal Components Analysis (PCA) of water quality parameters from semi-intensive culture of hybrid surubim. $\mathrm{O}_{2}=$ Dissolved Oxygen; $\mathrm{Op}=$ Orthophosphate; Trasp= Transparency; Cond= Eletrical Conductivity; Temp= Temperature; Alk= Alkalinity; Fe= Iron; $\mathrm{C}=$ Cold season; $\mathrm{H}=$ Hot season.

In the PCA from the intensive system, the joint representation of the two main factors accounted for approximately $68 \%$ of the variance. There was diffuse relationships between the seasons and water quality parameters. However, higher conductivity values were more related with the cold season (Figure 2). 

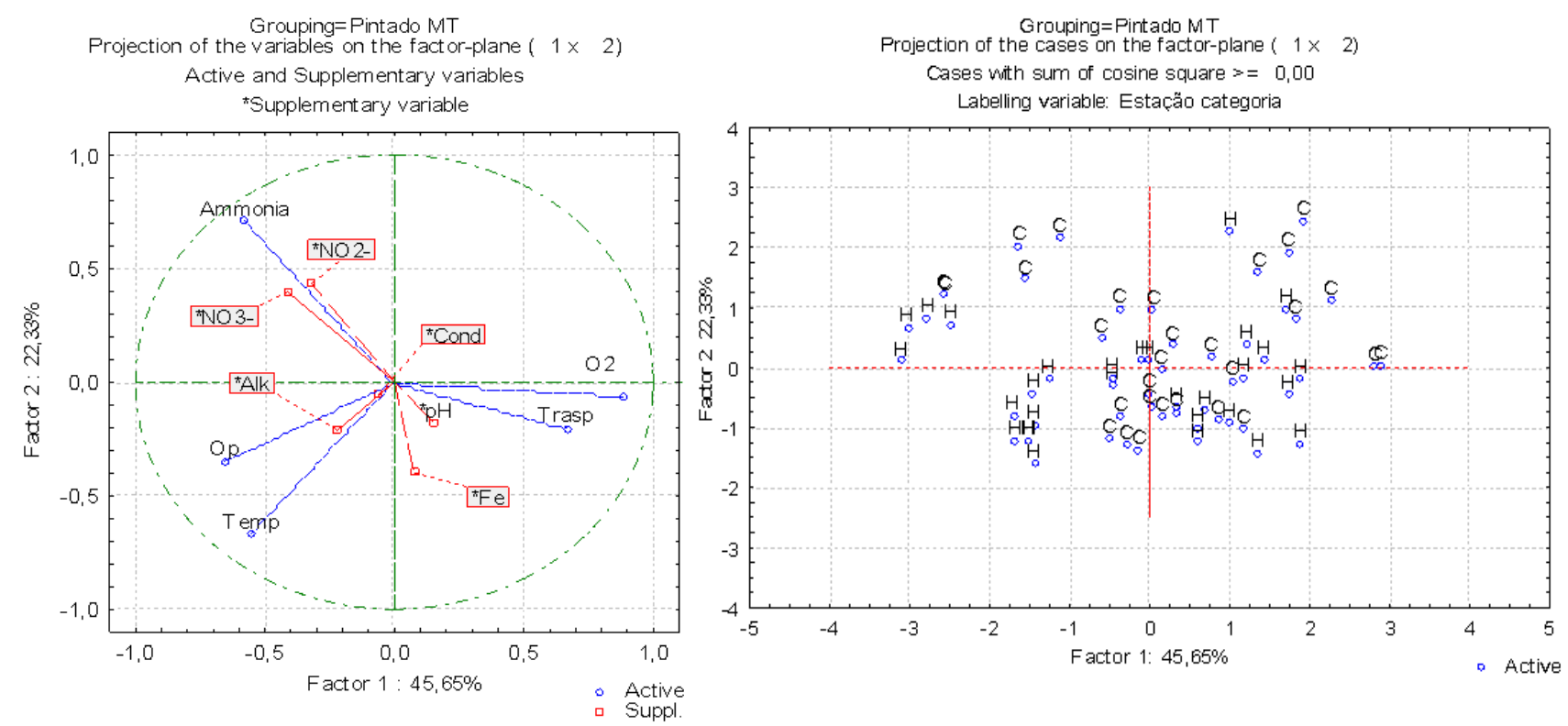

Figure 2 - Principal Components Analysis (PCA) of water quality parameters from intensive culture of hybrid surubim. $\mathrm{O}_{2}=$ Dissolved Oxygen; $\mathrm{Op}=$ Orthophosphate; Trasp= Transparency; Cond= Eletrical Conductivity; Temp= Temperature; Alk= Alkalinity; Fe = Iron; $\mathrm{C}=$ Cold season; $\mathrm{H}=$ Hot season.

Hematology has been widely used as an important tool for monitoring the health status of fish farming, allowing inferences about their healthiness conditions (Ishikawa et al. 2010). Hematological parameters are likely to change according to the changes of the aquatic environment; they can help to understand the process of adaptation of animals to their environment (Ranzani-Paiva et al. 2005) and provide references to identify any changes in the condition fish health (Ranzani-Paiva et al. 1997). This type of monitoring is important in aquaculture, given that the conditions imposed by the cultivation affect the basic physiological functions of farmed fish due to submission to stressors (Tavares-Dias and Moraes 2007).

The body weight of the animals showed a significant difference $(p<0.05)$ between the seasons and was higher in the cold season than in warm, depending on the actual fattening period. However, there was no significant change in length (Table 2). Fish from the intensive system had higher mean hematocrit in the cold season, however, total plasma protein, hemoglobin, MCV and MCHC. WBC values were higher in the hot season, but there were no significant differences in the numbers of RBC, thrombocytes, lymphocytes, neutrophils, monocytes, eosinophils, basophils and PAS-LG between the seasons. In the animals from the semi-intensive pond, the cold season was also followed by a significant increase in hemoglobin, MCHC and MCV ( $\mathrm{p}<0.05)$.

Hematocrit values in this study were within the range of values reported by Tavares-Dias et al. (2009); however, these were higher when compared to other studies of hybrid surubim (Beelen et al. 2003; Ishikawa et al. 2010; Mouriño et al. 2012). There was also an increase during the cold season in fish intensive system, with values significantly higher than those animals from the semi-intensive ponds in the same season as shown by significantly higher amounts of erythrocytes. Since the values of erythrocytes were similar to those reported in the literature for this hybrid, the hematocrit was high due to the high MCV of erythrocytes.

In the hot season, the numbers of RBC and thrombocytes were higher, but no significant seasonal influence was observed on hematocrit, total plasma protein, WBC, lymphocytes, neutrophils, monocytes, eosinophils, basophils and PAS-LG (Table 2).

Comparing the farming systems within the same season, the total plasma protein values were higher in the semi-intensive culture in comparison to intensive fish farming, both in cold as in hot seasons. In the cold season, animals from the semi-intensive culture also had higher levels of 
hemoglobin, MCHC and PAS-LG and lower hematocrit, erythrocytes, leucocytes and thrombocytes. In the hot season, the total numbers of leukocytes and thrombocytes were higher in the animals of intensive fish farming. In the hot season, there were no differences in hematocrit, hemoglobin, erythrocyte, MCHC, MCV, lymphocytes, neutrophils, monocytes, eosinophils, basophils and PAS-LG, while in cold season, the animals of both the systems showed similar values of MCV, lymphocytes, neutrophils, monocytes, eosinophils and basophils (Table 2).

Table 2 - Biometry and hematological parameters of hybrid surubim farmed in Brazil. PPT: total plasma proteins, MCHC: mean corpuscular hemoglobin concentration, MCV: mean corpuscular mean, PAS-LG: granular leukocyte PAS-positive.

\begin{tabular}{|c|c|c|c|c|}
\hline \multirow[t]{2}{*}{ Variables } & \multicolumn{2}{|c|}{ Intensive Farm } & \multicolumn{2}{|c|}{ Semi Intensive Farm } \\
\hline & Hot Season & Cold Season & Hot Season & Cold Season \\
\hline Weight (g) & $565.83 \pm 158.50^{b}$ & $637.77 \pm 114.80^{\mathrm{a}}$ & $939.38 \pm 383.48^{b}$ & $1203.73 \pm 409.20^{\mathrm{a}}$ \\
\hline Lenght $(\mathrm{cm})$ & $42.23 \pm 3.34$ & $42.35 \pm 6.12$ & $48.93 \pm 5.35$ & $49.97 \pm 5.35$ \\
\hline PPT (g.dL $\left.{ }^{-1}\right)$ & $4.68 \pm 0.39^{\mathrm{bB}}$ & $5.41 \pm 0.64^{\mathrm{aB}}$ & $6.19 \pm 1.30^{\mathrm{A}}$ & $6.35 \pm 0.65^{\mathrm{A}}$ \\
\hline Hematocrit $(\%)$ & $34.83 \pm 3.00^{\mathrm{b}}$ & $37.09 \pm 4.19^{\mathrm{aA}}$ & $33.05 \pm 7.30$ & $32.93 \pm 6.82^{B}$ \\
\hline Hemoglobin $\left(\mathrm{g} \cdot \mathrm{dL}^{-1}\right)$ & $3.14 \pm 0.72^{b}$ & $7.35 \pm 3.65^{\mathrm{aB}}$ & $3.74 \pm 0.93^{\mathrm{b}}$ & $8.65 \pm 3.31^{\mathrm{aA}}$ \\
\hline Erythrocyte $\left(\mathrm{x} 10^{6} \cdot \mu \mathrm{L}^{-1}\right)$ & $2.23 \pm 2.04$ & $1.96 \pm 0.51^{\mathrm{B}}$ & $1.92 \pm 0.36^{\mathrm{a}}$ & $1.57 \pm 0.26^{\mathrm{bA}}$ \\
\hline $\mathrm{MCHC}\left(\mathrm{g} \cdot \mathrm{dL}^{-1}\right)$ & $9.04 \pm 2.06^{\mathrm{b}}$ & $20.03 \pm 10.00^{\mathrm{aA}}$ & $1.72 \pm 3.46^{\mathrm{b}}$ & $28.97 \pm 17.26^{\mathrm{aB}}$ \\
\hline $\mathrm{MCV}(\mathrm{fL})$ & $179.84 \pm 41.61^{\mathrm{b}}$ & $202.76 \pm 59.68^{\mathrm{a}}$ & $178.57 \pm 53.24^{\mathrm{b}}$ & $215.89 \pm 65.00^{\mathrm{a}}$ \\
\hline Total Leukocyte $\left(\times 10^{3} \cdot \mu \mathrm{L}^{-1}\right)$ & $71.83 \pm 31.85^{\mathrm{aA}}$ & $61.43 \pm 18.69^{\mathrm{bA}}$ & $52.59 \pm 25.46^{\mathrm{B}}$ & $46.39 \pm 16.83^{\mathrm{B}}$ \\
\hline Thrombocyte $\left(\times 10^{3} \cdot \mu \mathrm{L}^{-1}\right)$ & $43.10 \pm 26.61^{\mathrm{A}}$ & $42.99 \pm 20.47^{\mathrm{A}}$ & $29.81 \pm 21.33^{\mathrm{aB}}$ & $21.90 \pm 15.86^{\mathrm{bB}}$ \\
\hline Lymphocyte $\left(\times 10^{3} \cdot \mu \mathrm{L}^{-1}\right)$ & $64.17 \pm 27.65$ & $54.20 \pm 17.16$ & $46.58 \pm 23.74$ & $40.68 \pm 15.93$ \\
\hline Neutrophil $\left(\times 10^{3} \cdot \mu \mathrm{L}^{-1}\right)$ & $4.58 \pm 3.86$ & $4.86 \pm 3.12$ & $3.41 \pm 2.26$ & $3.21 \pm 3.00$ \\
\hline Monocyte $\left(x 10^{3} \cdot \mu \mathrm{L}^{-1}\right)$ & $0.78 \pm 0.88$ & $0.84 \pm 1.00$ & $0.30 \pm 0.51$ & $0.32 \pm 0.46$ \\
\hline Eosinophil $\left(\times 10^{3} \cdot \mu \mathrm{L}^{-1}\right)$ & $0.80 \pm 1.00$ & $0.42 \pm 0.54$ & $0.55 \pm 0.61$ & $0.30 \pm 0.38$ \\
\hline Basophil $\left(\mathrm{x} 10^{3} \cdot \mu \mathrm{L}^{-1}\right)$ & $0.86 \pm 1.38$ & $0.76 \pm 0.85$ & $0.70 \pm 0.74$ & $0.41 \pm 0.64$ \\
\hline PAS-LG $\left(x 10^{3} \cdot \mu \mathrm{L}^{-1}\right)$ & $0.64 \pm 0.98$ & $0.39 \pm 0.61^{\mathrm{A}}$ & $0.97 \pm 1.58$ & $0.76 \pm 0.77^{\mathrm{B}}$ \\
\hline
\end{tabular}

*Lowercase letters indicate significant differences $(\mathrm{p}<0.05)$ between stations. capital letters indicate significant differences between sites within the same season.

In the cold season, the average hemoglobin concentrations were similar to those reported by Labarrère et al. (2012) for the surubim hybrid in different densities of stock. Fish from both the systems showed a reduction in hemoglobin concentration in the hot season. Santos et al. (2012) observed an increase in hemoglobin in the summer. During this season, the availability of dissolved oxygen in the water was lower and the metabolic activity of the fish increases. The MCHC showed hemoglobin values similar to Labarrère et al. (2012) and Dias-Tavares et al. (2009) in the cold season; during the warm season, there was a significant reduction in both local cultivation. Lower CHCM values are indicative of anemia (Labarrère 2012), which may also indicate a higher proportion of young erythrocytes, since they do not possess adequate amount of hemoglobin (Tavares-Dias et al. 2009). This may be the case due to concomitant low MCV and elevated number of erythrocytes. During the cold season, animals from the semi-intensive ponds showed higher values of hemoglobin and MCHC compared to fish from the intensive system, which indicated reduced dissolved oxygen in the water. The red blood cell MCV was higher than the values reported by Mouriño et al. (2012), but was within the recorded by Tavares et al. (2009) for hybrid surubim. MCV was reduced in the warm season in both the places. In the case of semiintensive culture, this change was accompanied by an increase in the number of erythrocytes. Therefore, the lower values of MCV were due to the higher amount of immature red blood cells (Affonso et al. 2002), recruited to optimize the oxygen transport, as the hot season was usually related to lower concentrations of dissolved oxygen in the water. The erythrocyte volume is also related to activity level (Glazova 1976, Wintrobe 1934), being higher when the animal is more sedentary. Thus, the increase in MCV in the cold season could be strongly associated with a decrease in metabolic activity and locomotion of animals, which reducesd the oxygen demand.

The total plasma protein concentrations were similar to those observed by Ishikawa et al. (2010) and Dias-Tavares et al. (2009) in hybrid surubim. 
Plasma proteins are responsible for vital functions such as carrying of metabolites, humoral defense and coagulation (Tavares-Dias et al. 2009). In the animals from the intensive system, a significant increase of this parameter occurred in the cold season, while in the semi-intensive ponds, it remained unchanged. Similar to that observed in fish from the semi intensive ponds, De Pedro et al. (2005) and Swain et al. (2007) observed no seasonal change in this parameter. The increase that occurred during the cold season was still within the variation described by Tavares et al. (2009). Total protein was altered primarily by the changes in plasma volume, with increases normally related to loss of plasma fluid into the intracellular compartment. This occurs by osmotic imbalance between the intracellular and extracellular compartments, thus any stress that induces such an imbalance can lead to increased plasma protein (Milligan and McDonald 1992). Previous studies have shown that stress increases the amount of total serum proteins (Milligan and Wood 1986; Milligan and McDonald 1992; Melo et al. 2009). In this study, the cold season was associated with increased concentrations of ammonia, which could be an additional stress factor, associated with the high density and temperature reduction. Regarding the system of cultivation, animals from semi-intensive systems ponds showed higher total plasma protein in both seasons. Hrubec et al. (2000) observed higher values in fish from intensive cultivation compared with fish raised at low density.

The values of erythrocytes were similar to those reported in the literature for this hybrid (TavaresDias et al. 2009; Mouriño et al. 2012). In semiintensive ponds, higher values were observed during the warm season, as also reported by Jerônimo et al. (2011), De Pedro et al. (2005) and Guijarro et al. (2003). Given that this season was related to lower concentrations of dissolved oxygen in the water, it could be stated that the fish increased red blood cell production to improve oxygen transport capacity, compensating for the reduced availability (Jerônimo et al. 2011). During the cold season, the animals of the intensive system ponds had higher erythrocyte, therefore, it was possible that in this system the concentrations of dissolved oxygen were lower, also demonstrating a compensatory effect.

The WBC count and thrombocytes number in blood may be indicative of the health status of fish (Tavares-Dias and Moraes 2007). In the fishes from semi-intensive ponds, it was similar to that reported by Mouriño et al. (2012) and Silva et al. (2012) for hybrid surubim, while in the intensive system, there was a tendency to higher values in both the seasons. This increase could be related to stress (Martins et al. 2004) due to higher densities and more intense management. The animals in intensive system showed an increase in the number of leukocytes in the hot season, supporting the studies of Morgan et al. (2008), De Pedro et al. (2005) and Collazos et al. (1998).

The number of thrombocytes in fish from the semi-intensive ponds was similar to that reported for the hybrid surubim by Mouriño et al. (2012) and Silva et al. (2012), but in the intensive system, higher values were similar to those reported by Tavares-Dias et al. (2009), which showed no seasonal variation, while fish from the semiintensive ponds had more thrombocytes in the hot season. Thrombocytes participate in blood coagulation and may also possess defense function (Martins et al. 2008). Seasonal variation found in the WBC and thrombocytes number supported Schreck and Slater (1998) hypothesis that the immunological behavior usually consisted of increase in the summer and decrease in winter. According to Engelsma et al. (2003), lower temperature affects both the quantity and function of immune cells.

Regarding the differential leukocyte count, none of the mentioned parameters showed a significant difference between seasons, a result also reported by Swain et al. (2007). The numbers of lymphocytes were similar to those reported by Mouriño et al. (2012) in hybrid surubins that received dietary supplementation with prebiotic and/or probiotic, and higher than those observed by Tavares-Dias et al. (2009) in hybrid surubins cultured in Mato Grosso do Sul. The numbers of neutrophils were higher than those reported by Mouriño et al. (2012), slightly higher than those found by Tavares-Dias et al. (2009) and similar to the findings of Mouriño et al. (2012), where hybrid surubins were supplemented with probiotics and challenged with or without Aeromonas hydrophila. The values of monocytes were below those reported by Tavares-Dias et al. (2009), and in the intensive system, were similar to those observed by Mouriño et al. (2012), but fish from the semi-intensive ponds showed lower monocytes values than those observed by TavaresDias et al. (2009) and Mouriño et al. (2012). The higher number of monocytes found in fish from 
the intensive system could be associated with higher stocking density.

In relation to eosinophils, the average values were similar to those reported by Tavares-Dias et al. (2009) and Mouriño et al. (2012) for this hybrid. Basophils appeared similar in the quantity to those observed by Mouriño et al. (2012), but dramatically higher than those reported by Tavares-Dias et al. (2009). Regarding PAS-LG, quantities were similar to those reported by Mouriño et al. (2012), being higher in the feefishing ponds than in intensive system during the cold season. According to Schalch et al. (2005), changes in the amounts of PAS-LG are related to stress and may be caused by parasitism. Similar was observed by Ranzani-Paiva et al. (1987) on the high-frequency of this cell in carps parasitized by Argulus sp. It was possible that the reduction in the efficiency of the immune system was associated with the cold season, which made the fish more susceptible to parasitism.

\section{CONCLUSION}

The present results demonstrated the influence of the seasons on the hematological values of hybrid surubim kept in intensive and semi-intensive ponds of fish farm. The reduction in the number of WBC along with the increase in MCHC, MCV, hematocrit and total plasma protein in intensive culture system during the cold season could be related to the need to improve the body's defenses during this season. The increase in hemoglobin concentration, MCHC, MCV and a reduction in the number of thrombocytes animals from semi intensive ponds, could be related to system maintenance.

\section{REFERENCES}

Affonso EG, Polez VLP, Corrêa CF, Mazon AF, Araújo MRR, Moraes G, Rantin FT. Blood parameters and metabolites in the teleost fish Colossoma macropomum exposed to sulfide or hypoxia. Comp Biochem Physiol. 2002; Part C 133:375-382.

Beelen R, Boyd B,Garavello JC, Pavanelli GC, Ainsworth AJ. A cytochemical, light and electron microscopic study of the peripheral blood leucocytes of hybrid surubim catfish (Pseudoplatystoma corruscans x Pseudoplatystoma fasciatum). Comp Clin Path. 2003; 12: 61-68.

Campos JL. O cultivo do pintado Pseudoplatystoma corruscans (Spix e Agassiz, 1829). In: Baldisserotto
B, Gomes LC (eds.). Espécies nativas para piscicultura no Brasil. Editora UFSM, Santa Maria; 2005. p. 327-343.

Collazos ME, Ortega E, Barriga C, Rodriguez AB. Seasonal variations in haematological parameters in male and female tench (Tinca tinca). Mol Cel Biol. 1998; 183: 165-168.

Collier HB. The standardizations of blood hemoglobin determinations. Can Med Assoc J 1944; 50: 550-552.

Crepaldi DV, Faria PMC, Teixeira EA, Ribeiro LP, Costa AAP, Melo DC, Cintra APR, Prado SA, Costa FAA, Drumond ML, Lopes VE, Moraes VE. O surubim na aquacultura do Brasil. Rev Bras Reprod Anim. 2006; 30: 150-158.

De Pedro N, Guijarro AL, Lopez-Patiño MA, MartínezÁlvarez R, Delgado MJ. Daily and seasonal variatons in haematological and blood biochemical parameters in the tench, Tinca tinca Linnaeus, 1758. Aquac Res. 2005; 36:1185-1196.

Engelsma MY, Hougee S, Nap D, Hofenk M, Jan HW, Rombout M. Multiple acute temperature stress affects leucocyte populations and antibody responses in common carp, Cyprinus carpio L. Fish Shellfish Immunol. 2003; 12:61-76.

FAO. FIGIS - Fisheries and aquaculture information and statistics service, 2013.

Goldenfarb PB, Bowyer FP, Hall E, Brosius E. Reproductibility in the hematology laboratory: the microhematocrit determinations. Am J Clin Pathol. 1971; 56:35-39.

Glazova TN. Physiological and biochemical blood characteristics of some species of tropical fish from the Pacific Ocean J Ichthyol. 1976; 16:95-105.

Guijarro AI, Lopez-Patiño MA, Pinillos ML, Isorna E, De Pedro N, Alonso-Gómez AL, Alonso-Debate M, Delgado MJ. Seasonal changes in haematology and metabolic resource in the tench. J Fish Biol. 2003; 62:803-815.

Hrubec TC, Cardinale JL, Smith SA. Hematology and chemistry reference intervals for cultured tilapia (Oreochromis hybrid). Vet Clin Pathol. 2000; 29:712.

Ishikawa NM, Ranzani-Paiva MJT, Lombardi JV. Total leukocyte counts methods in fish, Oreochromis niloticus. Arch Vet Sci. 2008; 13:54-63.

Ishikawa MM, Pádua SB, Satake F, Hisano H, Jerônimo GT, Martins ML. Heparin and $\mathrm{Na}_{2}$ EDTA as anticoagulants for hybrid surubim catfish (Pseudoplatystoma reticulatum $\mathrm{x} \quad P$. corruscans): efficacy and hematological changes. Ciência Rur. 2010; 40:1557-1561.

Ishikawa MM, Pádua SB, Satake F, Martins ML, Tavares-Dias M. Morphological identification of Anaplasmataceae-like organisms in monocytes of the hybrid surubim catfish (Pseudoplastystoma reticulatum $x$ P. corruscans). Rev Bras Med Vet 2011; 33:225-228. 
Ishikawa MM, Pádua SB, Ventura AS, Jerônimo GT, Russo MR, Carrijo Mauad JR, Martins ML. Biology and Sanitary Strategies in Carnivorous Catfish Fingerlings. Embrapa Agropecuária Oeste. Documentos, 115. [internet]. 2012 [cited 2013 Apr. 01]. Available from: http://www.infoteca.cnptia.embrapa.br/handle/doc/94 5230. Acessed 01 Apr 2013.

Jerônimo GT, Lafitte LV, Speck GM, Martins ML. Seasonal influence on the hematological parameters in cultured Nile tilapia from southern Brazil. Braz J Biol. 2011; 71:719-725.

Labarrère CR, Faria PMC, Teixeira EA, Melo MM. Erytrogram of hybrids surubins (Pseudoplatystoma corruscans $x \quad P$. reticulatum) kept at diferente stocking densities. Arq Bras Med Vet Zootec. 2012; 64:510-514.

Martins ML, Mouriño JL, Amaral GV, Vieira FN, Dotta G, Jatobá AMB, Pedrotti FS, Jerônimo GT, Buglione-Neto CC, Pereira JG. Haematological changes in Nile tilapia experimentally infected with Enterococcus sp. Braz J Biol. 2008; 68:631-637.

Martins ML, Pilarsky F, Onaka EM, Nomura DT, Fenerick JJ, Ribeiro K, Myiazaki DMY, Castro MP. Haematology and acute inflammatory response of Oreochromis niloticus (Osteichthyes: Cichlidae) submitted to a single and consecutive stress of capture. Bol Inst Pesca. 2004; 30:71-80.

Melo DC, Oliveira DAA, Melo MM, Junior DV, Teixeira EA, Guimarães SR. Proteic electrophoretic profile of chitralada tilapia nilotic (Oreochromis niloticus), exposed to hypoxia chronic stress. Arq Bras Med Vet Zootec. 2009; 61:1183-1190.

McDonald DG, Milligan CL. Chemical properties of the blood. In: Hoar WS, Randall DJ, Farrel AP (eds.) Fish Physiology, San Diego, 1992; p.55-134.

Milligan CL, Wood CM. Intracellular and extracellular acid-base status and $\mathrm{H}^{ \pm}$exchange with the environment after exhaustive exercise in the rainbow trout. J Exper Biol. 1986; 123: 92-121.

Morgan AL, Thompson KD, Auchinache NA, Migaud $\mathrm{H}$. The effect of seasonality on normal hematological and innate immune parameters of rainbow trout Oncorhynchus mykiss L. Fish Shell Immunol 2008; 25:791-799.

Mouriño JLP, Vieira FN, Jatobá A, Silva BC, Jesus GFA, Seiffert WQ, Martins ML. Effect of dietary supplementation of inulin and W. cibaria on haematoimmunological parameters of hybrid surubim (Pseudoplatystoma sp.). Aquac Nutr. 2012; 18:73-80.

Naldoni J, Arana S, Maia AAM, Ceccarelli PS, Tavares LER, Borges FA, Pozo CF, Adriano EA. Henneguya pseudoplatystoma $\mathrm{n}$. sp. causing a reduction in epithelial area of gills in the farmed pintado, a South American catfish: Histopathology and ultrastructure. Vet Parasitol. 2009; 166:52-59.
Ranzani-Paiva MJ, Ishikawa CM, Portella MC, Celiberto RJ. Hematologia da carpa comum Cyprinus carpio, infestada por Argulus sp. e após um tratamento com fosfato de 0,0-dimetil-oxi-2,2tricloroetilo (Neguvon). Bol Inst Pesca. 1987; 14:8392.

Ranzani-Paiva MJT, Ishikawa CM, Campos BES, Eiras AC. Haematological characteristics associated with parasitism in mullets, Mugil platanus Günther, from the estuarine region of Cananéia, São Paulo, Brasil. Rev Bras Zool. 1997; 14:329-339.

Ranzani-Paiva MJT, Romagosa E, Ishikawa C. Hematological parameters of "cachara" Pseudoplatystoma fasciatum Linnaeus, 1766 (Osteichthyes, Pimelodidae), reared in captivity. Bol Inst Pesca. 2005; 31:47-53.

Schalch SHC, Belo MAA, Soares VE, Moraes JRE, Moraes FR. Eficácia do diflubenzuron no controle de Dolops carvalhoi (Crustacea: Branchiura) em jovens pacus Piaractus mesopotamicus (Osteichthyes: Characidae) naturalmente infectados. Acta Sci Anim Sci. 2005; 27:297-302.

Silva BC, Mouriño JLP, Vieira FN, Jatobá A, Seiffert WQ, Martins ML. Haemorrhagic septicaemia in hybrid surubim (Pseudoplatystoma corruscans $\mathrm{X}$ Pseudoplatystoma fasciatum) caused by Aeromonas hydrophila. Aquac Res. 2012; 43:908-916.

Slater CH, Schreck CB. Season and physiological parameters modulate salmonid leucocyte androgen receptor affinity and abundance. Fish Shell Immunol. 1998; 8:379-391.

Swain P, Dash S, Sahoo PK, Routray P, Gupta SD, Meher PK, Sarangi N. Non-specific immune parameters of brood Indian major carp Labeo rohita and their seasonal variations. Fish Shellfish Immunol 2007; 22: 38-43.

Tavares-Dias M, Moraes FR. Leukocyte and thrombocyte reference values for channel catfish (Ictalurus punctatus Raf), with an assessment of morphologic, cytochemical, and ultrastructural features. Vet Clin Pathol. 2007; 36:49-54

Tavares-Dias M, Ishikawa MM, Martins ML, Satake F, Hisano H, Pádua SB, Jerônimo GT, Sant'Ana AR. Hematologia: Ferramenta para o monitoramento do estado de saúde de peixes em cultivo. In: Saran Neto A, Mariano WS, Sória SFP (eds)Tópicos Especiais em Saúde e Produção Animal. São Carlos, 2009; p. 43-80.

Wintrobe MM. Variations in size and hemoglobin content of erythrocytes in the blood of various vertebrates. Folia Haematol. 1934; 51: 32-49.

Zaniboni-Filho E. Piscicultura das espécies nativas de água doce. In: Poli CR, Poli ATB, Andreatta ER, Beltrame E (eds.). Aquicultura: Experiências Brasileiras. Florianópolis, 2004; p 337-363. 